\title{
Action Research on Blended Learning Transformative Potential in Higher Education- Learners' Perspectives
}

\author{
Hisham Dzakiria, Mohd Sobri Don@ A.Wahab \& Hamzah Dato’ Abdul Rahman, PhD \\ Executive Development Centre, Universiti Utara Malaysia, Malaysia
}

Received: January 13, 2012

Accepted: May 8, 2012

Online Published: June 15, 2012

doi:10.5430/bmr.v1n2p125

URL: http://dx.doi.org/10.5430/bmr.v1n2p125

\begin{abstract}
This article reports on action research on Blended learning approach conducted in 2011. The goal of the research was to investigate students' perspectives towards blended approach (hybrid) in teaching Business Communication as the learner progresses through their Executive program at Executive Development Centre, Universiti Utara Malaysia. Results indicated that students were in favor of BL. Students felt they learned as much or more than they did in traditional method of teaching and learning, were more motivated, and preferred hybrid courses over traditional ones. Specifically, the research finding suggests that BL has the potential of enhancing learning interactivity and minimizes the sense of isolation amongst the learners. The authors found that students felt a greater sense of belonging in those courses that used synchronous communication, although they enjoyed the flexibility of asynchronous communication.
\end{abstract}

Keywords: Blended learning, Learners' Perspectives, Pedagogy, New Ways to Learn \& Teach, Business Communication

\section{Introduction}

Blended learning means many things to many people. The definitions that exist today are varied, and could be vastly similar or different. It is quite often been thought to be synonymous to the term 'hybrid' learning. In general terms, blended learning combines online delivery of educational content with the best features of classroom interaction and live instruction to personalize learning, allow thoughtful reflection, and differentiate instruction from student to student across diverse group of learners.

Definitions of blended learning range from some so broad that practically any learning experience that integrates some use of educational technology might qualify, to others that focus on a specific percentage combination of online curriculum and instruction in a face-to-face setting. A few of the many definitions of blended learning include:

- The integration of face-to-face and online learning to help enhance the classroom experience and extend learning through the innovative use of information and communications technology. Blended strategies enhance student engagement and learning through online activities to the course curriculum, and improve effectiveness and efficiencies by reducing lecture time Whitelock, D. \& Jefts, A. (2003), Alavi \& Gallupe (2003).

- A course that blends online and face-to-face delivery. Substantial proportion of the content is delivered online, typically uses online discussions, and typically has some face-to-face meetings Arbaugh (2005), Peterson (2003), Procter (2003) and Dzakiria et.al (2006).

- The combination of multiple approaches to learning. Blended learning can be accomplished through the use of 'blended' virtual and physical resources Alavi \& Gallupe (2003), Singh, (2003).

The array of definition on BL seems to suggest that it integrates learning programs in different formats to achieve learning. Most often, blended learning programs integrate classroom and online programs. Rossett, Douglis, and Frazee (2003), Albrecht (2006) and Arbaugh (2005) insert that anything can be blended into blended learning, whether it be classroom and e-learning, two or more types of e-learning, or two or more types of off-line learning. They suggest that blended learning programs blend material presented from the traditional classroom, live virtual classroom, and asynchronous instruction (Rossett, Douglis, \& Frazee, 2003). And with the advent of digital technology blended learning takes on new dimensions and merges the best features of conventional face-to-face instruction and online learning (Graham, 2006). Today's framework of blended learning replete with various blends and models that makes it difficult for educators to concur with a single definition of blended learning (Graham, 2006; Procter, 2003). 
For the purposes of this action research, we describe BL as a hybrid of multi-modality of teaching and learning approaches that includes combination of face to face (f2f) teaching with a combination of one or more repertoires of teaching and learning tools that supports the learning interaction between instructor-student-content. These include the employment of various technologies, pedagogy, or andragogy approaches: Case studies, Problem based learning and others synchronously and asynchronously. In addition, we also believe that a blended learning approach must be student-centered and uses a selection process that converge educational tools and media for maximum learning and impact on the leaners;promotes the use of practical media, technology and learning resources for learning purposes; inviting (different, exciting, and fun that draws enthusiasm to learners); and offers a variety of interaction through stimuli and activity.

Adult learning principles, and advances in technology collectively point to blended learning as in increasingly finest method for workplace learning. There have been numerous studies suggesting that blended learning do better than instructor-led programs (Thompson Job Impact Study, 2003). Blended learning can capitalize on adult learning needs and workplace maturity by providing self-directed, relevant experiential learning, social interaction, and access to knowledge, at the same time as being cost effective and efficient.

For organization and educational institutions, BL can also extend the reach of the program, optimize development costs and time and accelerate the dissemination of knowledge to vital channels (Singh and Reed, 2001) and reach the mass population. It has the potential to help any country or institution to democratize education to all citizens. Its flexibility nature is its strongest alternative to promote lifelong learning anywhere, and anytime. Blended learning can deliver workplace learning to organization and learner in a highly flexible and customized manner. Such flexibility is deemed important, and in many ways is a strong factor that invites adult learners to learn (Dzakiria et.al, 2006). Many of them do not have the luxury and means to leave work and family for education or training which has always been a barrier for adult learning to take place.

Based on the definitions given in the literature, organizations and institutions of higher learning must now account for blended learning in all its various façades (Webster, J. \& Hackley, P. (1997). It is becoming an integral part and parcel of teaching and learning, and becoming the contemporary pattern to reach learners wherever they may reside and work. Blended learning supports the linkages between instructors, learners, and content. Therefore, better understanding of BL, and subsequently improving its potential is imperative to support the Malaysia government Lifelong Learning initiatives on democratizing education for all in the country.

\section{Research Conceptual Framework}

Students' learning experience and performance can be improved when educational technology and ICT are integrated with traditional forms of course delivery, such as face-to-face lectures and tutorials (Stacey and Gerbic, 2007). However, if the technology is not used effectively to support learning, and not linkedin any way to the learners', there is a risk that students will become disenchanted and reduces potential benefits to the learners (Love and Fry, 2006).

Technology is never meant to be a perfect solution to any educational issues. It however, is intended to be an enabler to better teaching and learning experiences. Therefore, the extent to which new technology is employed in courses needs to be carefully considered to ensure that it meets the needs of the learners (Deed and Edwards, 2011). It is important to understand the various aspects of particular learning environments that are related to improvements in students' performance so that limited resources can be applied where they are most effective. Some studies like Mayes, (2002); Love and Fry, (2006); Dzakiria (2006), and Greenwald et al., (1996).

Further, blending the learning resources can provide a range of functions for learners and teachers to give some real benefits to traditional learning environments, such as reducing the time-lag between production and utilization of materials and the free sharing of information (Floridi, 1995). When properly designed and implemented, the use of BL empowers students by giving them the freedom and responsibility to control their learning environment (Becker and Dwyer, 1994).

In order for BL to improve learning outcomes, it must be shown to be doing more than merely developing flexibility in the delivery of course materials. What is really needed is an environment which will provide students with an environment that enhances learning and enables students to control their learning space and develop a variety of learning styles (Follows, 1999). The objective of this study is to elicit students' perspectives on BL in relation to performance.

\section{Research Objectives}

This paper presents the students' point of viewing on BL methodology while completing their course/module within 
the Executive Diploma program at Universiti Utara Malaysia. The objective of this research is to elicit students' perspectives and experiences taking Business Communication course within their Executive Diploma program with Blended Learning adopted as the teaching and learning pedagogical method.

\section{Research Background}

This qualitative case study focused on the experience of a small number of students undertaking Business Communication module within their Executive Diploma in Organizational Leadership in Manufacturing Management at Executive Development Centre Universiti Utara Malaysia (UUM).

\section{Research Methodology}

An instrumental qualitative case study (Stake 1995) approach was employed so as to understand the experience of individual learners as they progressed through their Executive Diploma studies at UUM. The research used interview as the primary instrument. All the learners (research participants) involved in this study were interviewed on a one-to-one basis, and this was the basis of the data reported in this paper.

The interview guide functions as an interview protocol and helped to ensure good use of limited interview time available during the fieldwork. Most of the interviews were conducted in Bahasa Malaysia, and English language was only used when necessary and possible. The interviews were then transcribed, translated and profiled. Besides face to face interviews, the respondents also engaged and probed into more questions through e-mail, SKYPE and chat interviews which all contributed to a substantial amount of data for the research.

\section{Research Participants \& Background}

Due to the heterogeneous characteristics of the adult learners, this study purposely engaged with learners with various backgrounds to generate their unique and meaningful insights on $\mathrm{BL}$ and the learning experience they encountered while completing the module. 16 students participated in the study. They come from various education and family background. The average age of the participants were 39 , with the youngest was 22 and the oldest was 48 . The participants are all Sabahan from different ethnic background.

\section{Research Setting and Duration}

The research setting was located in Tawau, Sabah, East Malaysia in August 2011. The respondents come from different cities and localities in Sabah. The research commenced early August and was completed in late September 2011. The face to face interview was conducted after class completion, and was subsequently continued through emails, chat and SKYPE.

\section{Business Communication Module}

This module is one of the nine total mandatory modules that must be completed within the Executive Diploma Course offered by the Executive Development Centre, Universiti Utara Malaysia. Like other modules, Business Communication Module is a two day course developed to train, and improves the participants' communicative competency so that they become effective and functional communicators. The course aims to improve organizational communication aspects to contemporary human-relations and business practices at the work place.

The course is developed to teach and improve the students' ability to:

- Communicate effectively with proven communication techniques and tools;

- Build relationship in a way that builds and maintains effective business relationships;

- Understand various business communication approaches;

- Apply business communication theory to real business situation;

- Develop critical thinking skills in business communication; and

- Influence and persuade others in business.

Each module is normally taught by different instructors who are empowered to teach based on their individual style and approach. The course module is generally given, and form as the primary reference for the individual module. Given the length and duration for each module is limited at best, it is a challenge for any research to be conducted in relation to individual module or program. For most part of it, lecturers are much more concerned completing the module successfully within the given time. However, our research interest and passion for course improvement, Open Distance Learning (ODL), Adult learning, and Student-Centeredness warrants us to investigate if a change in teaching and learning approach would make the learning outcome for students much more meaningful and inviting. 
The business communication environment differs from other setting in that most business communication professionals need to have effective communication skills to survive the trade that they are in. Communicating effectively, negotiating skills, selling, persuasions are some of the survival skills that they need to have to prosper in their career. The Executive Diploma course is an in service training and is intended to improve, enrich and disseminate new information and knowledge to learners. It is therefore important for tertiary institutions to develop courses that provide such essentials in a more meaningful and inviting way and interactive.

\section{Blending the Teaching \& Learning Approaches}

This action research is intended to study the effects of blending various approaches and pedagogical approach to teaching Business Communication would make a difference in students' performance. Instead of just using the course module as the primary reference within the two days of class engagement, various technology and approaches were blended into the teaching and learning experience. These changes include:

- The PPTs were linked to various relevant YouTube videos to discuss various issues on business communication.

- Students were invited to join various 5-minutes role-play which was also followed by rich discussion on selected topics.

- Engaging short case studies were given as over-night reading and reflection for day two in-class activity.

- Students' reflection and interaction on various activities were pursued. The course was made to be engaging with a 30:70 ratio, with much of the interaction and reflection comes from the students.

- The instructor functioned more as facilitator, and this was intended to empower the learners into their learning.

- The students were then given the course assignment, and had a month to complete for submitting it to the course instructor.

- Post-Training/class time - Students were invited to join the forum within LMS (UUM Learning Zone) that was used. Various additional learning materials were uploaded for learning purpose.

- Various discussion topics were also given in the forum for group discussion. Within the one-month period, the students were engaged to reflect on their perspective and review of the teaching and learning of Business Communication Module.

- Finally, the students have to submit their course assignment which is based primarily on students' working experiences, personal case, and what was learned and discussed during the 2 days face to face class, and all other form of educational discussion within the LMS, emails, SKYPE and SMS.

\section{Learners' Perspectives}

In general, student satisfaction and student learning outcomes have been consistently higher with blended learning method adopted in Business Communication as compared to other teaching and learning approaches used in other modules offered within the Executive Diploma program.

The following section of this paper presents and analyses students' discourse on two themes: Blended Learning offers Richer Learning Interaction; and Re-engineering New Ways of Teaching \& Learning. The section concludes discussing some implications of the findings.

\section{Blended Learning Increases Learning Interaction}

While there is much variation in blended courses, one apparently consistent finding is student satisfaction with this approach in teaching and learning. Students are positive regarding the flexibility and convenience and the perceived increase in interaction they have with BL.

Students rate the quality of their blended experience as high as or higher than other modules they have taken within the Executive program. They also report high satisfaction with instructor interaction. Students indicated that the intuitive structure of the course - clearly defined objectives, assignments, deadlines, and encouraging dialogue and interaction-was most important to their satisfaction with the course. The openness in class discussion and the ongoing online interaction on various topics in the module, and the use of case studies have contributed to learners understanding the course content better as revealed by the following discourse:

It was great. This is my $7^{\text {th }}$ module, and this one is very different in nature. The first $6^{\text {th }}$, I think the students were taking a passive role, listening, and more listening...this one, I had to take an active role.... Like it...and was never tired or sleepy... 
Empowering.....I enjoyed it; wish all other instructors do the same...

As an adult learner I think the respect for us is there...our experience is turned into sharing and learning which is great...

I think the approaches used in the teaching of the content that makes a big different...I learn better, and am highly motivated to attend the class

This is my 8 module, and it is one of the best...the class is so relax but meaningful and interactive. I am always a shy student and do not talk much, but this course employs a teaching approach that force you to talk about your own working experiences, and eventually I talk a lot and enjoying it...

The teaching approach offers students to share and learn. I learn so much from this module...too bad it was just a short module

Makes more sense to use our learning experiences and individual case study for learning purpose....it is practical and eye opener.

The above comments seem to suggest and support the notion that adult learners are different than younger or non-working learners. Their working experiences could be made a learning resource and may provide rich context for learning. These experiences must be blended into the teaching and learning. In addition, we have to realize that adults don't just "learn" in one way. Quite often, adult learners are learners that have much more experiences (i.e. relevant working experiences) compared to young learners like the undergraduate students, and it is imperative that those experiences be shared for learning purpose.

\section{Blended Learning Minimizes Feeling of Isolation}

In addition to the above, BL helps to minimize the feeling of isolation and alienation. The BL adopted with strong student-centered paradigm within the Business Communication has helped many of the learners to participate in a more meaningful way in the learning process. In particular, the learners said:

Learning has always been difficult for me. Communication is difficult. I do not talk much. I am very quiet and very extrinsic in nature. But, when the teaching and learning incorporates a lot of learning activities that requires you to read, reflect, talk and present...overtimes it become better, stronger and I enjoyed the change. I get to learn about people business communication problems that occur within various organizations that my friends in the class work with shared my thoughts...bottom-line a great learning experience...

The instructor call for openness in discussion, and use if multimedia to communicate and not just requiring a f2f is good for overall learning. When there is no right-or wrong and respecting various views it makes the learning more interactive and playful...

Between the power point, the case studies, the discussion and sharing and openness...the course is so much inviting. I think if this approach is utilized more, difficult courses can be made easier and manageable...

The LMS and forum, the introduction of SKYPE for discussion purpose was great...the course helped me to think and participate....

Human contact and Interaction is vital to ensure the effectiveness of learning (Dzakiria \& Idrus, 2003) and it mediates the learner-content-learner-teacher interaction. In many ways as depicted by the learners in this course that, BL offers them an opportunity to lead discussion, and to share with others. This represents the core in student-centered approach. This concurs with Herbert Simon claims that "Human beings are at their best when they interact with the real world and draw lessons from the bumps and bruises they hit "(Simon, 1994: p.74). This view of the adult learner is not new, but teachers need to take Simon's comments to heart if they are to be successful. Education offers students a far greater range of opportunities. They are no longer forced to sit and listen to material deemed irrelevant, simply to fulfill graduation requirements. Relevance of subject matter and the way it is communicated are critical.

\section{Blended Learning Offers Mixture of Learning Resources}

The BL also provided several linked options for learners, in addition to classroom training; the learners were exposed to various potential learning resources which contributed to a richer learning experience as depicted by the following discourse:

We just want more....The YouTube, Videos is just fun to watch... and you learned a great deal...

The web, internet, case study and videos are superb....wish all other modules incorporate such technology....I love technology

Who says YouTube is all bad...use it wisely...it is rich and meaningful for learning

The teaching approach allows you quite often to visualize situation....things that maybe abstract or difficult at first, but made into something that is more understandable..... 
The YouTube was great. It was fun, entertaining, yet you get much of the learning content from it. I wish all other modules use this as an alternative to those boring one-way teaching....it was total black and white. But this module was colorful....

The BL approach gave the sense that the students not only learned more when online sessions through the LMS were added to traditional courses, but student interaction and satisfaction improved as well as shown below:

I may be the oldest in class, and remembered how my age proves to be a challenge for me and my classmates to engage in discussion or to interact. But, Business Communication I think change all that. The approach used is so effective. It builds on respecting others, and valuing other ideas in a more relax environment. It is so easy to throw ideas around. The case studies and life examples from classmates made it so cool...

Practically, we the students were in the driving seats of the class....we led most of the class discussion. The instructor functions more as a facilitator and was great at that. It helps us to interact and learn more...

The discourse this far, seems to suggest that speedier performance was detected on real world tasks by those who learned through blended strategies as opposed to those that learned the module through traditional way of teaching which incorporated much of the teacher-centered paradigm. The findings thus far seem to suggest that educators, trainers, and institutions must continuously assess how we teach and provide learning and training. In many ways, and in order to survive, institutions have to change, be creative and innovate, and blending the teaching approaches is definitely one way forward that we have to consider. As instructors we have to undo the old ways and learn the new ways of teaching and learning.

\section{Discussion and Analysis}

While it is important, in designing effective modules and programs to understand how learning occurs, and the factors that influence the learning process; understanding who adult learners are, not only their characteristics, but the impact of former educational experiences, what motivates them to seek an Executive Diploma learning experiences, and how they accommodate the role of a learner in addition to other life roles is crucial and hence, development of meaningful education programmes (Merriam \& Cunningham, 1989). Approaches to course design, for example, often emphasise teaching strategies from an instructional perspective that assumes good teaching, and that effective teachers will produce good learning, but this may not be true for every learner.

Good teaching logically helps learning, but in adult learning, there is much more than good teaching and good teachers to make learning a worthwhile effort for every learner. From the learners' perspective, the way they respond to instruction and the factors involved in learning are worth investigating.

And, in general, the evidence revealed in this study shows that there is no universal view of what constitutes good, effective teaching and learning, as approaches preferred by the learners in this study may be those disliked by others. However, there is ample evidence here to suggest that 'we' have to in some ways and degree examined how we teach and provide learning especially to adult learners.

As iterated in Rob Walker's (2002), teaching is always thought to take place in classrooms, “...the images that first come to mind are of a teacher in the classroom... (p.2)" and for most this signifies a precise setting and environment. This and independent learning, presents a common challenge to many adult learners in Malaysia, particularly those who have left educational settings for many years. The issue of balancing one's educational experience with a contemporary way of learning is an area of concern in today's higher education in the country. Though the idea of the classroom is not strictly relevant in ODL, or online courses, the image persists. There are many people, particularly students, who think that learning is something that happens in a classroom, with teachers feeding information face to face (f2f). Such thinking and educational concepts of learning are still vivid and active. A false expectation it may be, but it seems that some learners are unable to learn in the new context, or favouring a BL approach, until they unlearn the old one. Changing their thinking and mind-set is evidently a challenge that requires serious attention particularly in a BL paradigm as depicted by the following students' discourse:

For most part, I enjoyed the course, but being a matured student getting to 46 now of age, sometimes when there is a requirement to do a lot of reflection on your own, group work, reading and digesting case studies on your own ...it is not easy. I think being a product of a spoon-feeding teaching approach in Malaysia mainly from my primary and secondary years, this constitute a problem.

Overall, I like Business Communication module and the instructor. It is different; I think we as students talk more.... which in my years of education do not happen quite often. Great for change, and I think the combination of readings, activities, role play and case studies that we did naturally motivate us to say few things and have fun in the class... 
A different way of teaching, unlike other modules you sometimes felt sleepy and be yawning half way...Business Com. is different. I really enjoyed the role play...it is fun, and I did not even realize I can act. The role play simulate real situations and therefore gives you real learning. Wish all the modules incorporate this...I want more

Absolutely a different learning experience as compared when I was in school and college 18 years ago.... you need to learn and re-learn...or you will be left behind...

Today, with the advancement of technology, educators would claim that classroom is not necessary for learning and that millions of students around the world have already discovered that learning can happen at any time, place and in any setting. It is no longer necessary to be in a classroom in front of a teacher to be in a 'place of learning'. Conventional ideas about education are undergoing a transformation as the concepts lifelong learning gain popularity. Lifelong learning advocates that learning can occur anytime, and anywhere if one wants to learn, There is much opportunity available today than before. It should come as no surprise that the learners recognised that participating in today's educational program involved 'change' on a different level. Most notable were the perceptions of learning to work more independently and having to adopt more active ways of learning and interacting. Once this is supported, that learning would then become easier to conduct.

It did not take much time for the learners to notice the similarities between traditional learning (in-class), with those at a distance, online, or blended. In fact, the word distance does not entail proximity anymore. Much of these varied educational means and tools have been converged in one way or the other. What needs attention is to transform these learners to have the educational 'change' and know-how to survive and learn effectively within today's learning environment. Institutions of higher learning need to provide an optimal learning support system.

$\mathrm{BL}$ is contemporary in nature. It is different from traditional learning experiences that many Malaysia students undergo within their 12 years of conventional education. Malaysian learners in general have cultural orientations towards learning which make educational experience with BL difficult to grasp (at least during its introductory approach). The Malaysia learners are more reserved, and are sometimes passive participants in classroom discussion. As a result, they sometimes feel at loss when clear instructions are not given for work, assignments, and experiments.

\section{Possible Barriers to Blended Learning}

When designing a blended learning program the needs of the students must be balanced with the outcomes expected by the institution. Teachers as good as they may be in the traditional classroom need further training so that implementation of the course is not hampered by a mismatch of content and technology. Finally the teacher and the students need to understand the collaborative nature of the new learning endeavor so that a balance will be struck and motivation to learn will remain.

The fact remains that proper planning on teaching and learning can predictably affect $\mathrm{BL}$ - positively if planned well but negatively if attention has not been paid to the conditions under which learning best occurs. In reality its importance has been undervalued. Many measures of educational institution effectiveness neglect the students' point of viewing, and context of learning. They focused instead on the selection and performance of staff, and learners and on the technology used. Effective learning support should be designed to enable students to concentrate on their studies, free from distracting elements. Learning support should facilitate learning and access to knowledge. It is thus imperative that lecturers have an in-depth understanding of learning support impact on learners when designing a BL approach for a course.

Inherent in the nature of BL is a sense of individual autonomy in the learner, which may be valued but which may also cut across traditional values. The learners are not always given immediate feedback, which may come with $\mathrm{f} 2 \mathrm{f}$ interaction in a traditional course. 'Feedback' here means more interactions than just comments on learners' written work, and more reassurance from lecturers reiterating a point or responding to a question asked by a learner.

Learners are sometimes unsure of the lecturers' meaning when interpreting the lectures and materials without having this level of reassurance. This in turn may cause the learners to experiment with many different possibilities for meaning, thereby constructing their own knowledge and making connections to situations that are more meaningful to them, but at the risk of 'being wrong'.

The degree of uncertainty in this process can cause learners to lose self-control, power to make decision and courage. They make mistakes, and continued errors may demotivate them from learning successfully. This in turn may lead to failure and withdrawal and could be a possible 'push factors' towards BL.

Despite possible learning barriers faced by the learners caused by their own sets of beliefs, and perceptions on learning, we must come back to the teachers' attitudes towards teaching. As in any educational situation, the teachers set the tone for learning in the educational environment. Nevertheless, setting the right tone to produce good teaching and learning experience may not be an easy task. 
Quite often, the default position according to Walker (2002) “...seems to be that teaching requires only the addition of a few skills not already in the repertoire of the conventional teacher to teach using technology and educational resources. That once in place, most courses can run... (p.113).

This approach is questionable particularly when implementing such a model means providing some technical support to conventional 'trained' teachers. Walker (2002: p.113) further iterated that:

Implementing an adult learning programme requires new forms of pedagogy, though these are not always fully recognised and are less easily replicated than is often assumed. Those implicated need time and resources as well as technical assistance to make the changes that this requires.

\section{Teacher Continuous Induction on Contemporary Teaching Approach}

University teachers must be properly trained and motivated to be effective. This means that the teacher has a responsibility to help students learn by making sure that the demands of the teaching-learning context are pedagogically sound (Laurillard, 1993).

They must have the 'know-how' and confidence to use all of the various educational technologies and resources in order to be truly effective in teaching. Teachers must also change the manner in which information is delivered. When the lecture mode does not work well, other media and learning activities like the multimedia presentations, role play are successful (Weber 1996).

This means more preparation time for the teacher and the motivation must be there. Walcott (1994), cited in Carter (2001) found in a study of adult learning that "to effectively bridge the gaps between classroom and teaching, faculty need to look at the teaching from the learners' point of view" (pg. 249). The teachers must also be aware of getting instructional materials, hand-outs, tests, and other class items to learners on time. It is important for the teachers to develop a sense of community, achieve maximum participation, and get the learners to be engaged and get involved in the process.

According to research by Palloff and Pratt (2000), "collaborative learning processes assists learners to achieve deeper levels of knowledge generation through the creation of shared goals, shared exploration, and a shared process of meaning making" (pg. 6). It is up to the teachers to be aware of this in the learning environment and to encourage collaborative learning and a sense of community among the learners.

Another important consideration for the teachers is their view regarding the goal of education. There are two main thoughts on this. Schlosser and Anderson (1994, cited in Imel, 1998) put this thought forward. They submit that the goal of education is "to offer the student an experience as much like that of traditional, face-to-face instruction as possible" (p.3). This would mean that the contemporary learning pedagogy would not differ much from that used in an ordinary classroom. Bates (1995) has a different idea. He suggests that instead of using technology to replicate traditional methods, it should be used to improve instruction and learning. Holmberg (1989) also discusses these two schools of thought and concludes that various type of education offerings (i.e. online education, distance education, hybrid education, etc.) as a mode of education in its own right has very different consequences (than viewing it as a substitute for face-to-face instruction). The teachers must decide which attitude they will adopt, because it has a profound impact on their approach to instruction, as evident in this study, discussed earlier.

\section{Conclusion}

This action research suggests that there are various benefits of BL (hybrid) approach. These include pedagogical richness- providing an innovative shift from a presentational format to active learning which harness student centeredness; greater access to personalized learning, resources and experts; greater flexibility and accommodation for learners and teachers of diverse backgrounds; increased interaction and sense of community; and increased cost-effectiveness. Most important of all, BL provides more meaningful, inviting and fun learning which contribute to a better learning experience and interaction. (Albrecht, 2006; Dziuban, Moskal, \& Hartman, 2004; Vaughan, 2007; Dzakiria et.al. 2006).More specifically, blended learning offers the following advantages:

- Blended learning can be made student sensitive. The design must consider the students' profile and background for a better learning outcome; Students must be made part of the learning resource and material to optimize learning opportunity;

- Blended learning harnesses on student centered paradigm; Malaysia students must be given the leading role in their own learning for knowledge. The learning culture moving away from teacher-centered approach to learner-centered must be sustained and improved;

- Blended learning offers a convergence of $\mathrm{f} 2 \mathrm{f}$ teaching with technology and maximizes learning. BL allows instructors to plan and present lower level thinking and critical thinking appropriately to tap on students' 
ability. The classroom segment uses role plays, case studies, and other discovery learning procedures that explore higher order thinking about real-life issues and situations;

- Blended learning can help reduce total training time and minimize time away from the job for training. Although many enterprises are committed to workplace learning, they face the practical reality of tight budgets and need for workers to quickly acquire new skills and knowledge;

- More effective than traditional way of teaching. Higher learner value and impact; the effectiveness greater than for non-blended approaches

These findings are consistent with those reported in a study by Thomson (2002) which found that learners who participated in a blended program performed enjoyed their learning experiences much more than those modules that were delivered using traditional methods (i.e. teacher-centered, chalk and board, one-way teaching)

\section{References}

Alavi, M. \& Gallupe, and R. B. (2003). Using Information Technology in learning: Case studies in business \& management education programs, Academy of Management Learning \& Education, 2(2), pp.139-154. http://dx.doi.org/10.5465/AMLE.2003.9901667

Albrecht, B. (2006). Enriching student experience through blended learning. ECAR Research Bulletin, 12.

Arbaugh, J. B. (2005). How Much Does "Subject Matter" Matter? A study of disciplinary effects in on-line MBA courses, Academy of Management Learning \& Education, 4(1), pp. 57-73. http://dx.doi.org/10.5465/AMLE.2005.16132549

Bates, A. W. (1995). Technology, Open Learning and Distance Education. London: Rout ledge.

Becker, D. A. and Dwyer, M. N. (1994). Using hypermedia to provide learner control, Journal of Educational Multimedia and Hypermedia, 3(2), 155-172.

Carter, A. (2001). Interactive distance education: Implications for the adult learner. International Journal of Instructional Media, 28 (3), 249-261.

Deed, C. and Edwards, A. (2011). Unrestricted student blogging: Implications for active learning in a virtual text-based environment, Active Learning in Higher Education, 12 (1), 11-21. http://dx.doi.org/10.1177/1469787410387725

Driscoll, M. (2002). Blended learning: Lets get beyond the hype, E-learning. Available at http://elearningmag.com/Itimagazine. Retrieved on Retrieved July, 29, 2010.

Dzakiria, H., Mustafa C.S. \& Bakar, H.A. (2006). Moving Forward with Blended Learning (BL) as a Pedagogical Alternative to Traditional Classroom Learning, Malaysian Online Journal of Instructional Technology(MOJIT), Vol. 3, No.1, pp. 11-18.

Dzakiria, H. \& Idrus, R. (2003). Teacher-Learner Interactions in Distance Education: A case of Two Malaysia Universities, Turkish Online Journal of Distance Education, 4(3).

Dziuban, C. D., Hartman, J. L., \& Moskal, P. D. (2004). Blended learning. ECAR Research Bulletin, 7. Retrieved April 27, 2008 from http://net.educause.edu/ir/library/pdf/erb0407.pdf

Floridi, L. (1995). Internet: which future for organized knowledge, Frankenstein or Pygmalion? International Journal of Human-Computer Studies, 43(2), 261-74. http://dx.doi.org/10.1006/ijhc.1995.1044

Follows, S. B. (1999), Virtual learning environments, $T$ H E Journal, 27(4), 100-106.

Graham, C. R. (2006). Blended learning systems: Definition, current trends, and future directions. In C. J. Bonk and C. R. Graham (Eds.), Handbook of Blended Learning: Global Perspectives, Local Designs. San Francisco, CA: Pfeiffer Publishing.

Greenwald, R., Hedges, L. V. and Laine, R. D. (1996). The effect of school resources on students achievements, Review of Educational Research, 66 (3), 361-96.

Holmberg, B. (1989). The concept, basic character, and development potentials of distance education. Distance Education, 10 (1), 127-135. http://dx.doi.org/10.1080/0158791890100110

Imel, S. (1998). Myths and Realities of Distance Learning. Columbus, Ohio: ERIC Clearinghouse on Adult, Career, and Vocational Education. Ohio State University. (Eric Document Reproduction Service No. ED 414 446).

Kerres, M. \& De Witt, C. (2003). A didactical framework for the design of blended learning arrangements, Journal of Educational Media, 28(2-3), pp.101-113. http://dx.doi.org/10.1080/1358165032000165653

Kolb, D. (1984). Experiential learning: experience as the source of learning and development. Eaglewood Cliffs, NJ: Prentice Hall. 
Knowles, M.S. (1990). The adult learner. A neglected species. 4th edition. Houston, Texas: Gulf Publishing.

Laurillard, D. (1993). Rethinking University Teaching: A Framework for the Effective Use of Educational Technology, London: Rout ledge.

Love, N. and Fry, N. (2006). Accounting students' perceptions of a virtual learning environment: Springboard or safety net? Accounting Education: an international journal, 15(2), 151-166.

Mayes, T. (2002). The technology of learning in a social world, in: R. Harrison et al. (Eds) Supporting Life Long Learning: Volume 1 Perspectives on Learning, 163-175 (London: Routledge Falmer).

Merriam, S.B., \& Cunningham, P.M. (1989). Adult learners and the educational process. In S. B.

Merriam \& P. M. Cunningham (Eds.), Handbook of Adult and Continuing Education, (pp. 181-182). San Francisco: Jossey-Bass.

Moore, C. (2004). Using models to manage strategic learning investments. http://www.clomedia.com/content/templates/clo_feature.asp?articleid=579\&zoneid=31

Palloff, R., \& Pratt, K. (2000). Making the transition: Helping teachers to teach online. Paper presented at EDUCAUSE: Thinking it through. Nashville, Tennessee. (ERIC Document Reproduction Service No. ED 452 806).

Peterson, P.M. (2003). New Directions to the Global Century, Frontiers: The Interdisciplinary Journal of Study Abroad, 9, pp.189-198.

Procter, C. (2003). Blended learning in practice. Proceedings of Conference on Education in a Changing Environment 2003. Salford, UK: The University of Salford.

Rossett, A., Douglis, F. \& Frazee, R.V. (2003). Strategies for building blended. Retrieved from Learning Circuits on May 29, 2011 from http://ablendedmaricopa.pbwoks.com/f/Strategies\%20Buildings\%20Blended \%20Learning.pdf

Schlosser, C.A., \& Anderson, M.L. (1994). Distance Education: Review of the literature. Washington DC: Association for Educational Communications and Technology.

Simon, B. (1994). The two Nations and the educational Structure 1780-1870, Lawrence and Wishart, London.

Singh, H. and Reed, C. (2001). A White Paper: Achieving Success with Blended Learning. Centra Software White Paper Series. Retrieved Oct, 2011 from www.centra.com/download/whitepapers/blendedlearning.pdf.

Singh, H. (2003). Building effective blended learning program, Educational Technology, 43(6), pp.51-54

Stacey, E. and Gerbic, P. (2007). Teaching for blended learning: research perspectives from on-campus and distance students, Education and Information Technologies, Vol. 12, 165-174, Springer, USA. http://dx.doi.org/10.1007/s10639-007-9037-5

Stake, R. E. (1995). The Art of Case Study, Thousand Oaks, CA: Sage Publications.

Thomson NETg. (2003). Thomson Job Impact Study: final results, the next generation of corporate learning: achieving the right blend. 2003. Feb, [cited 2005 Nov 5]. Retrieved on Retrieved Jan, 11, 2012 from http://www.netg.com/Upload/uk_ThomsonJobImpactStudy.pdf

Vaughan, N. (2007). Perspectives on blended learning in higher education.

International Journal on E-Learning, 6(1), 81-94.

Walker, R. (2002). Is there anyone there? The embodiment of knowledge in virtual environments. In C. Vraasidas \& G. Glass (eds.), Distance education and learning (pp.99-114), Greenwich, Connecticut: Information Age Publishing.

Weber, J. (1996). The Compressed Video Experience. Paper presented at Summer Conference of the Association of Small Computer Users. North Myrtle Beach, South Carolina. (ERIC Document Reproduction Service No. ED 405 838).

Webster, J. \& Hackley, P. (1997). Teaching Effectiveness in technology- mediated distance learning, Academy of Management Journal, 40(6), pp. 1282-1309. http://dx.doi.org/10.2307/257034

Wenger, E. (1998). Communities of practice: learning, meaning and identity. Cambridge, UK:

Whitelock, D. \& Jefts, A. (2003). Editorial: Journal of Education Media Special issue on blended learning, Journal of Educational Media, 28(2-3), pp.99-100. 